\title{
Social Justice as Environmental Justice. An interpre- tation of the Social Teaching of the Church from the practices
}

\section{Guillermo Otano Jiménez'}

\begin{abstract}
The Social Teaching of the Church has a long and rich history which started in the middle of the nineteenth century, in a time characterised by the rise of industrial capitalism and the need to address the "social question" in most European societies. Since the very beginning it was understood by many as an attempt to interpret the idea of social justice through the prism of Catholic religion. However, an interpretation of this kind is not a theoretical exercise that can be detached from social reality, but a reflection on social reality that focuses the attention on the worldly life of those who suffer the injustice. In this sense, the doctrinal body of the Church is alive and constantly evolving to adapt the teachings of the Gospel to the "signs of time".

The aim of this article is to analyse the practical implications of the recent developments in the interpretation of social justice made by the Social Teaching of the Church. I will do so focusing on two remarkable encyclicals: Populorum Progressio, which this year celebrates its fiftieth anniversary and the most recent Laudato $\mathrm{Si}^{\prime}$. The former invites us to contemplate the "social question" as a global issue that "ties all men together, in every part of the world"; the latter suggests that we "must integrate questions of justice in debates on the environment, so as to hear both the cry of the earth and the cry of the poor". I will illustrate the practical implications of this double movement analysing the main lines of work of the Conflict-Free Technology Campaign run by ALBOAN, a Jesuit NGO, since 2014.
\end{abstract}

Key words: sociology of religion, ecology, conflict minerals, civil society.

\footnotetext{
${ }^{1}$ Fundación Alboan.
} 
Fecha de recepción: 28-30 de junio de $2017^{2}$.

Fecha de admisión definitiva: 21 de junio de 2018.

\section{Justicia social como justicia ambiental. Una interpretación de la Enseñanza Social de la Iglesia desde las prácticas}

Resumen: La Doctrina Social de la Iglesia tiene una larga y rica historia que comenzó a mediados del siglo XIX, en una época caracterizada por el surgimiento del capitalismo industrial y la necesidad de abordar la "cuestión social" en la mayoría de las sociedades europeas. Desde el principio, muchos lo entendieron como un intento de interpretar la idea de la justicia social a través del prisma de la religión católica. Sin embargo, una interpretación de este tipo no es un ejercicio teórico que pueda separarse de la realidad social, sino una reflexión sobre la realidad social que centra la atención en la vida mundana de quienes sufren la injusticia. En este sentido, el cuerpo doctrinal de la Iglesia está vivo y evoluciona constantemente para adaptar las enseñanzas del Evangelio a los "signos de los tiempos".

El objetivo de este artículo es analizar las implicaciones prácticas de los desarrollos recientes en la interpretación de la justicia social realizados por la Doctrina Social de la Iglesia. Lo haré centrándome en dos encíclicas notables: Populorum Progressio, que este año celebra su quincuagésimo aniversario y el Laudato Si', más reciente. La primera nos invita a contemplar la "cuestión social" como un problema global que "ha tomado una dimensión mundial"; la segunda sugiere que se "debe integrar la justicia en las discusiones sobre el ambiente, para escuchar tanto el clamor de la tierra como el clamor de los
Justice sociale comme justice environnementale. Une interprétation de la doctrine sociale de l'Eglise depuis la pratique

Résumé: La doctrine sociale de l'Eglise a une histoire longue et riche qui commença au milieu du XIXème siècle à une époque caractérisée par le surgissement du capitalisme industriel et la nécessité d'aborder la «question sociale» dans la plupart des sociétés européennes. Depuis le début, beaucoupl'ont comprise comme une tentative d'interpréter la justice sociale à travers le regard de la religion catholique. Cependant, une interprétation de ce type n'est pas un exercice théorique qui puisse se séparer de la réalité sociale, mais une réflexion sur la réalité sociale qui fixe l'attention sur la vie mondaine de ceux qui souffrent l'injustice. Dans ce sens, le corps doctrinal de l'Église est vivant et en constante évolution pour adapter les enseignements de l'Évangile aux signes des temps.

L'objectif de cet article est d'analyser les implications pratiques des récentes réflexions interprétatives de la justice sociale faites par la Doctrine Sociale de l'Église. Je le ferai en me focalisant sur deux importantes encycliques: Populorum Progressio, dont on fête cette année le cinquantième anniversaire, et la plus récente Laudato $S_{i}$. La première nous invite à contempler la "question sociale» comme un problème global qui «est devenue mondiale»; la deuxième suggère que "doit intégrer la justice dans les discussions sur l'environnement, pour écouter tant la clameur de la terre que la clameur des pauvres». J'illustrerai les

\footnotetext{
${ }^{2}$ Fecha de celebración del Simposio.
} 
pobres". Ilustraré las implicaciones prácticas de este doble movimiento analizando las principales líneas de trabajo de la Campaña de Tecnología Libre de Conflicto dirigida por ALBOAN, una ONG jesuita, desde 2014.

Palabras clave: Sociología de la religión, ecología, minerales de conflicto, sociedad civil. implications pratiques de ce double mouvement en analysant les principales lignes de travail de la Campagne "Technologie libre de conflits» dirigée par ALBOAN, ONG jésuite, depuis 2014.

Mots clé: Sociologie de la religion, écologie, minerais de conflits, société civile.

\section{Introduction}

The link between faith and social justice is out of question in the recent history of Christianity. Its roots can be traced to the late stages of the modern era, in the middle of the nineteenth history. A period characterised by the rise of industrial capitalism in both sides of north Atlantic, but also by the awareness of its human and social costs. In most western societies, the social drivers of economic growth -such as industrialisation, urbanisation and the increasing rationalisation of social life- produced several non-intended consequences that were seen as a threat to the new social order (Bauman; 2005; Wagner, 2008). The technical innovations in farming left many peasants unemployed, so they had to move massively to the cities looking for a job in the brand-new industries. But, in many cases, the urban centres and even the factories were not prepared to accommodate the newcomers and provide jobs for all of them. As a result, an important part of the population was left behind, living in precarious neighbourhoods. Those lucky enough to find a job used to work under very bad conditions, including women and children. On the other hand, those who remained unemployed in newly industrialised societies, which were driven by a strong work ethos, became part of the so-called "new poor" (Bauman, 2005).

For more than a century, the "social question" -that is, the rising mass poverty and the subsequent social conflicts related with the access to basic goods such as food, health, labour rights, etc.- became one of the most worrisome issues for the European ruling class, who deemed the increasing inequality as a potential source of instability. The Catholic Church was not unaware of these problematics and their political implications in western societies. So, her commitment to the truth revealed by Jesus Christ had to be readjusted to the new realities produced by the industrial revolution. By the end of the nineteenth century, in 1891, Pope Leo XIII published his encyclical letter Rerum novarum, which can be considered as a foundational text of the Catholic social teaching in the modern era. In that text, Leo 
XIII addressed the living conditions of the working class and criticised the misguided answers offered by socialism and capitalism to the problem of distributive justice. That encyclical also included a brief genealogy of the idea of social justice, starting in the Bible until the moment of its publication, and highlighting the contributions made along the way by catholic thinkers such as Thomas Aquinas. Since then, many other theologists and Christian leaders have made significant contributions to the understanding of social justice.

The main idea that I defend in this article, following the writings of Severine Deneulin and Masooda Bano (2009), is that the approach of the Catholic social teaching to the idea of social justice, especially in the encyclicals, is always a reaction to the changes in the economic, social, political, cultural or spiritual context in which Christians live. It can be understood as an attempt to offer guidance to the Christians who face the changes in the world and need to interpret the new realities in the light of the Gospel. Of course, this kind of collective and premeditated interpretation of social reality does not happen on a daily basis, and when it does, is not an issue without contention among different Christian traditions. But, for reasons of clarity and concision, I will exclude history and power relations from my analysis. Instead, I will focus on the interpretation of justice that appears in the text of two encyclicals Populorum Progressio and Laudato Si', which were published with a gap of almost fifty years between each other ${ }^{3}$.

Both encyclicals offer a meaningful reflection on justice to those organisations and individuals who are involved in the practical dilemmas of global development. My argument is that the bridge between both texts invites us to rethink social justice as environmental justice. In order to illustrate this thesis, I will analyse the links between their diagnosis of the world and the translation of their principles into practices through a case of study: the Conflict-Free Technology Campaign run by ALBOAN, a Jesuit NGO, since $2014^{4}$.

\footnotetext{
${ }^{3}$ I will also quote other encyclicals and texts that have made significant contributions to the catholic understanding of social justice during the last century. The following documents will be referred by their initials, indicating the paragraph or the chapter quoted when necessary: Pacem in terris (PT), Gaudium et spes (GS), Mater et Magistra (MM), Populorum Progressio (PP), Caritas in Veritate (CV), Laudato Si' (LS).

${ }^{4}$ The methodology used to analyse this case of study is qualitative and has been based on participant observation techniques. During the last two years I have worked full-time in ALBOAN as advocacy officer for this campaign so I have first-hand knowledge of their goals and strategies. Participating in the campaign team also has helped me to reframe the dimensions of change that appear in the Table 1, under heading 4.1. I would like to thank all the members of the team for their willingness to collaborate with me in writing this article.
} 


\section{Populorum Progressio: introducing social justice into the field of development}

The encyclical Populorum Progressio by Pope Paul XVI came out in 1967, barely two years after the Second Vatican Council, or Vatican II, which took place during 1962-5. It is important to bear this in mind because, as Deneulin and Bano (2009: 136-142) have pointed out, it was the first council of the twentieth century and the world had evolved dramatically since the previous one (Vatican I) in 1869. After centuries of dominance, the decline of the European colonial powers was a reality. Two world wars had devastated the Old Continent, and soon after this the decolonisation process was recognised by the United Nations General Assembly. Even if the geopolitical map became divided by the East-West confrontation during the Cold War, the emergence of the Non-Aligned Movement -or the so-called "Third Wold" - was a sign of the increasing interdependence between countries and regions in a globalised world. This trend was also present in the organisation of Vatican II. In fact, if it can be considered as one of the most significant events in the history of Catholic Church, it is because

it was the first council to gather the universal, global, church, and not only its European centre, and the first one since the Reformation to include observers from the Reformed and Orthodox Churches. More than 2,000 people from all continents participated for three years in the discussions (óp. cit., p. 137).

In this sense, when Pope John XXIII convoked the Second Vatican Council, he was fully aware of the need to confront the multiple changes brought about by the new Age of Development ${ }^{5}$ and the globalisation of the modern world. Instead of neglecting this trend and looking for comfort in a dogmatic interpretation of the church's theology, he showed a firm commitment not only to update the social teaching of the Church, but to reform the organisation of the Church. According with Deneulin and Bano:

All the documents written during the Second Vatican Council were responses to the new context in which Christians tried to translate into social practices the fundamental teachings of Christianity. Because their existing practices had emerged in another context, they no longer embodied the core teachings of Christianity in the world's new context; a reinterpretation of how to live the truth revealed by Jesus Christ was required. The truth had not changed, but the interpretation of how to embody that truth in a concrete historical context certainly had (óp. cit., p. 141).

\footnotetext{
${ }^{5}$ This expression was popularised by Wolfgang Sachs in his Development Dictionary (SACHS, 1992). It refers to the forty years following World War II. A period characterised by the breakdown of European colonial Empires, the rise of the North-South divide and the increasing cooperation between nations through "development aid".
} 
In this sense, one of the most significant documents of Vatican II is the Pastoral Constitution of the Church in the Modern World, Gaudium et Spes, promulgated in 1965 by Pope Paul VI. In that text, Paul Vl emphasized some features of Catholicism that had direct implications in the field of development. For instance, the duty to "scrutinize the signs of time and interpret them in the light of the Gospel" (GS, 4) was understood basically as a commitment to the promotion of those institutions which expand human welfare. Along these lines, the third chapter, titled "Man's Activity Through the World", is an invitation to all believers to construct a more just social order, engaging with the principles of equity and justice in the social and economic struggles of their communities and assisting those in need first. Similarly, the fourth chapter, "The Role of Church in Modern World", makes a call to all Christians to act as "citizens of the world" (GS, 43). How to do that? Encouraging religious men working hand by hand with laymen, "establishing dialogue with the world and with men of all shades of opinion" (GS, 43). Other documents of the Vatican II point in the same direction:

a reform in the nature and structure of the Church that promotes dialogue with other Christian denominations and even with other religions in the transformation of the world in the light of the Gospel (Deneulin and Bano, 2009: 139).

The aggorniamento of the Catholic Church announced by John XXIII when he convoked the Vatican II, continued under the papacy of Paul VI. In fact, as was mentioned earlier, two years after closing the Council, in 1967, Paul VI published his encyclical Populorum Progressio. As one might expect from his title, this encyclical goes back to the subject of the Christian interpretation of human dignity and social justice. But it does so contextualising both issues in the frame of "development", especially on the need to promote "the development of peoples".

The preamble starts acknowledging "one important fact", namely, "the social question ties all men together, in every part of the world" (PP, 3). Two paragraphs below, the text reaffirms the desire of the Catholic Church "to fulfil the wishes of the [Second Vatican] Council and to demonstrate the Holy See's concern for the developing nations". And as a proof of her commitment, right after announces the creation of another pontifical commission, called Justice and Peace, whose mission is to "further the progress of poorer nations and international social justice, as well as help less developed nations to contribute to their own development" (PP, 5). But, as I will explain in the next section, this encyclical goes beyond the mere diagnosis of situation. It endorses a new approach to interpret human dignity and promote social justice, which could be termed as Integral Human Development. 
Against the conventional wisdom in the heyday of developmenteconomics, the Christian view of "development" does not reduce its meaning to the increasing income per capita, nor the gross domestic product (GDP). As Populorum Progressio stated: "To be authentic, [development] it must be well rounded; it must foster the development of each man and of the whole man" (PP, 14). This humanistic approach considers not only the material dimension of progress - which has an instrumental value-, but also the affective and spiritual dimensions of human well-being -which have an intrinsic value-. The importance of the former derives from its role as a means for promoting individual and collective welfare, whereas the latter are inherent to the conception of human dignity and essential to any comprehensive conception of human development. In this sense, the Integral Human Development approach promoted by the Social Teaching of the Church at the end of the 60s is in tune with other secular approaches to human development that came out over the following decades, such as the basic human needs approach in the 1970s and the 80s (ILO, 1976; Streeten et al. 1981) or even the human capabilities approach in the 90s (Nussbaum and Sen, 1993).

The common ground between these secular approaches to the assessment of human well-being and the religious approach to human development suggested by Populorum Progressio does not finish there. Regarding the diagnosis of the situation, both views agree on the ambivalence of economic growth driven by industrialization. For the experts in the field of development as well as for theologists, industrialization has played an important role increasing the wealth of nations - as the encyclical puts it, it is "a sign of development and as spur to it" (PP, 25). However, both approaches to well-being warn us about the dangers of the "superfluous wealth" (PP, 54) or the "pursuit of economic prosperity as an end in itself" (Sen, 1989: 42). According to Paul Vl's encyclical, these dangers are not only related to the increasing inequality in the distribution of wealth that characterised the economic "take-off" in some developing countries, but with the potential dehumanisation of society. As he points out: "the exclusive pursuit of material possessions prevents man's growth as a human being and stands in opposition to his true grandeur" (PP, 19). Integral Human Development, in this sense, is not about what you own, is about a life lived responsibly, embracing human dignity as a gift from God or, in secular terms, recognising human dignity as the main basis of modern human rights.

Another point of agreement between the secular and the Catholic approach to human development implicit in Populorum Progressio could be their critical view of the political ideologies of economic development. In a world split between those 
who defended free market capitalism and those who sympathised with communism, most of the academic pioneers of human development tried to stay away from the confrontation. Not because they were pretending to be apolitical, but because both ideological stances tended to put the means of economic growth before any other end -ignoring the human and social costs produced by autocratic regimes in many developing countries-. On the other hand, they defended the need to assess social justice focusing their analyses on the consequences that the social arrangements of each society produce on its population, that is, "putting people first" (Streeten et al. 1981). A similar stance seems to be adopted by Paul VI in this encyclical, which criticise "unbridled capitalism" (PP, 26), "the dangers of a planned economy" (PP, 33) or "technocracy" (PP, 34) by the very same reasons. Instead of accepting without questioning the solutions proposed by these political ideologies, he suggests we should embrace the process of "look, judge and act", proposed by John XXIII in his encyclical Mater et Magistra (MM, 236). Those are the three steps that have characterised the worldly orientation of the Catholic social teaching since the Second Vatican Council.

\section{Laudato Si’: social justice as environmental justice}

Published by Pope Francis on May 2015, Laudato Si' has caught the public imagination in a similar manner as Paul Vl's encyclical Populorum Progressio did when it came out, almost fifty years ago now. The expectations raised in both cases are related with the influence that each of them might have in the Social Teaching of the Church and, by the same token, in the world. In the year of its fifteenth anniversary, it can be said that this possibility is out of question in the case of Populorum Progressio, since the discursive changes brought by this encyclical have been widely accepted by Christianity. Many faith-based non-governmental organisations were created under the inspiration of Vatican II, and a good deal of them got engaged in the fight for social justice moved by Paul VI's reflection on global development.

Will it happen the same with the call to take care of our "Common House" made by Pope Francis in Laudato Si'? It is probably too early to say, but it would not be surprising, given the attention that has received so far. Right in the preamble it is made clear, following the example of John XIII in his Pacem in terris, that its message goes for "every person living on this planet" not only the entire "Catholic world" (LS, 3). The public of this encyclical is worldwide because the matters it addresses-such as climate change, environmental destruction, the "throwaway culture" inextricably 
linked to consumerism, etc.- are global and affect the entire humanity. It is true that theological reflection on Christianity has always paid attention to the beauty of God's creation. And, for the same reasons, there have always been theologists and other members of the Church who had warned about the need to protect it from human behaviour. Pope Francis quotes, in this regard, the efforts made by several leading members and past leaders of the Catholic Church -such as Saint Francis of Asisis, Francis's main inspiration, or the popes Paul VI, John Paul II or Benedict $\mathrm{VI}$ and even the Ecumenical Patriarchal Bartholomew, leader of the Orthodox Church since 1991-. But his own contribution with this encyclical deserves a prominent position in this genealogy of the Church's environmental awareness for the following reasons.

First, because Laudato $\mathrm{Si}^{\prime}$ shows an unusual willingness to strike up a public conversation which engages scientific reasoning, social movements, civic organisations, politicians and different secular and religious traditions of thought. It must be a conversation "which includes everyone, since the environmental challenge we are undergoing, and its human roots, concern and affect us all" (LS, 14). The invitation to engage in public reasoning is a constant reference throughout the entire text-suffice it to say that the word "dialogue" is mentioned thirty times and it has a central role in his call for action (LS, Ch.5)-. In this sense, the encyclical wisely makes clear that "the Church does not presume to settle scientific questions or to replace politics" (LS, 188). Neither does she aim to impose her voice over the rest. However, Francis believes that religion has a say in this debate, because the ecological crisis is not just an environmental issue that confront us with "the limits of growth". It is something else than that, it has human roots, and forces us to question our life-styles and how we live together. For these reasons, his diagnosis of the situation in the first part of the encyclical addresses not only the scientific facts about the problem (LS, Ch. 1), but also its theological (LS, Ch.2), socio-cultural (LS, Ch.3) and spiritual aspects (LS, Ch.6).

Secondly, Laudato $\mathrm{Si}^{\prime}$ will be remembered among other things for expanding our moral horizon with his defence of an integral ecology. Ethics normally refers to the moral dilemmas faced by men and women in their everyday life. It addresses the meaning of "right" and "wrong" when making a choice, confronting us with the criteria that guides our action and with their consequences over ourselves and our neighbours. In Christianity, the believer aspires to act following God's guidance as expressed in the word of the Gospel and the example of Jesus Christ. They accept responsibility for their present actions in front of their fellow human beings and under the gaze of God. But in Laudato Si', Pope Francis broadens the believers' sphere of ethical responsibility in two different ways. On the one hand, he invites 
us to consider also the way in which our individual and collective actions affect the environment. As he reminds us:

Nature cannot be regarded as something separate from ourselves or as a mere setting in which we live. We are part of nature, included in it and thus in constant interaction with it. (LS, 139)

Whatever we do to her we are doing it to ourselves, because we are both part of God's creation. And that is the reason why taking care of our "Common Home" should be part of our moral concern.

On the other hand, the principle of the common good, which has always played a key role in the catholic social teaching, gains a new meaning through the light of integral ecology. It still refers to "the sum of those conditions of human life which allow social groups and their individual members relatively thorough and ready access to their own fulfilment" 6 - a definition that matches perfectly with the conception of Integral Human Development defended fifty years before in Populorum Progressio. However, Laudato Si' invites us to broaden the scope of this view including the right of future generations to enjoy the same conditions as we did. It is a call to reflect on the environmental impact of our present lifestyles and their ecological sustainability. This process should lead us to initiate an "ecological conversion", one which allows us to take a fresh look at the justice of our institutions and social arrangements, our cultural patterns and their influence on our conception of human well-being. Understanding "social justice as environmental justice" from a Christian point of view, means to hold ourselves accountable-under the gaze of God-for our actions and their consequences on our fellow human beings and our shared environment.

I believe that this idea is probably the main legacy of Laudato Si'. Because, apart from its valuable contribution to the ethical and theological reflection, it is meant to inspire -among all kinds of people, not just religious men- new ways of engaging with sustainable practices in the development field. In the next section, I will illustrate this point focusing on the Conflict-Free Technology Campaign run by the ALBOAN, a Jesuit NGO from Spain.

${ }^{6}$ This definition was originally coined in Catechesis (15 April 2015): L'Osservatore Romano, 16 April 2015, p. 8.; and is quoted in Laudato $\mathrm{Si}^{\prime}$, par. 156. 


\section{ALBOAN's turn towards the issue of "conflict minerals"}

ALBOAN is a Jesuit international NGO founded in 1996. It is located in the Basque Country and Navarre, Spain, but it works side by side with many other local organizations from Latina America, Africa and India. Along with many people excluded by the system in which we live, ALBOAN works at building a global citizenship to denounce the injustices that cause inequality in the world, to build a culture that promotes the common good and to transform structures that generate poverty at the local and global level. To achieve this, ALBOAN works as a network with civic organizations and grassroots movements around the world. Its specific contribution to this collective construction has focused historically on the following topics: quality education, economic and productive development that is sustainable and equitable, humanitarian action in recurrent crises and inclusive democracy. In this sense, ALBOAN's mission is in line with the principles of Integral Human Development stated by the Catholic Social Teaching of the Church.

However, during the last decade, the Jesuit organization added a new topic after getting involved in a dialogue with its partners about the good governance of natural resources. This conversation was motivated by the fact that many of ALBOAN's allies in the Global South were affected by human rights abuses and environmental conflicts related with the increasing land grabbing strategies implemented by transnational corporations. One of the most controversial issues in this regard was the social and environmental impacts of the extractive activities, especially in the mining sector. The so-called "resource course" takes on a dramatic dimension in conflict zones and high-risk areas -places like the eastern part of the Democratic Republic of Congo, where ALBOAN works with the Jesuit Refugee Service of the Great Lakes-. The mineral reserves of tin, tantalum, tungsten and gold found in that region are some of the largest in the world. They worth millions of dollars, however, the DRC is one of the least developed countries in terms of human development according to the United Nations Development Programme (UNDP). Even if the struggles to take control over natural resources are not the main cause of the political instability in the region (as there are other economical, historical and ethnical factors), it is undeniable that they play a key role in fuelling that fire ${ }^{7}$.

\footnotetext{
7 The link between minerals and conflicts was known by the United Nations since 2001, when the first report was published. Since then, the Group of Experts on the DRC has published at least two more reports (S/2010/252 and S/2010/596) about this issue. The UN Security Council has also passed several resolutions identifying the actors involved, proposing sanctions and establishing a normative framework to cope with minerals trafficking (see resolution 1952 adopted in 2010) which was the basis for the OECD's Guidelines (2013).
} 
There are plenty of evidences that illustrate the links between the exploitation and illicit trade of tin, tantalum, tungsten and gold -also referred as 3TGs or informally identified as "conflict minerals" - and human right abuses in the eastern provinces of North and South Kivu, in the DRC. The smuggling of minerals is a regional problem since most of these precious metals and ores enter illegally in neighbour countries such as Rwanda or Burundi. But it has global roots, if we take into consideration that their destination is the smelters and refiners from South-East Asia that supply the international industries. The unique properties of these minerals make them a highly valuable asset for the technological companies that manufacture electronic devices such as mobile phones, laptops, tablets and so on.

The dark side of the trade on conflict minerals has been addressed by the United Nations and other international institutions, such as the Organization for the Economic Co-operation and Development (OECD), which launched the OECD Due Diligence Guidelines for Responsible Supply Chains of Minerals from Conflict-Affected and High-Risk Areas in 2011. The Guide, as it is known, establishes a 5-step framework of due diligence as a basis for responsible supply chain management of minerals, including tin, tantalum, tungsten and gold, as well as all other mineral resources. It is largely supported by the 35 OECD Members and 8 non-Members countries (Argentina, Brazil, Colombia, Costa Rica, Lithuania, Morocco, Peru and Romania), which adhered to the Council Recommendation. On the international stage, the OECD Guidelines can be considered as the main benchmark against to assess the business practices in the responsible sourcing of conflict minerals. However, it is not a binding instrument and its recommendations are not mandatory, so one can expect -for very good reasons- that its influence on corporations and businesses alike can be very limited if not unreal.

That is the reason why many international NGO, grassroots organizations and global social movements have been demanding the translation of these voluntary principles into binding regulations. This demand was met first in the USA, after the 2008 economic crash. Back in 2010, two years after the financial crisis hit, forcing the US government to use taxpayer money to bail out the banks, then President Obama approved the Wall Street Reform Act, also known as the Dodd-Frank Act. Its purpose was to protect consumers from financial industry abuse by providing tighter regulations and promoting corporate transparency. Considering the unique opportunity for correcting market dysfunctions and fighting against lack of transparency, the legislators included one clause, section 1502, which requires those American companies using 3Ts and Gold to implement due diligence systems if these resources come from conflict zones in the DRC and nine adjoining countries. 
Four years later, in 2014, the European Commission announced its compromise to start a legislative process in the same vein as the US Congress did in order to promote responsible sourcing of tin, tantalum, tungsten, and gold the so-called "conflict minerals"- among European industries. That was interpreted as a window of opportunity by many international NGOs to push towards an effective European regulation on responsible sourcing of minerals coming from high risk areas. Such a law would make corporations more accountable, forcing them to implement due diligence systems which can detect and prevent human right abuses in their supply chains. And, accordingly, it would help to cut the funds obtained illicitly by the organized crime and the armed groups operating in the eastern part of DRC which have been benefitting from the smuggling of minerals for decades.

ALBOAN decided to join the coalition of NGOs that was created after the Commission's announcement in order to follow up the legislative process in Brussels and the rest of Member State's capitals. By that time, the Jesuit organization already had decided to launch a specific campaign called Conflict-Free Technology. Its aim would be to raise awareness among the citizenship about the links between the illicit trade on conflict minerals, the human rights violations in the mining sites of the eastern part of DRC and the consumerism of electronic devices which has been driving up the demand of these natural resources during the last two decades.

\section{Conflict-Free Technology Campaign: Promoting "conversion" at three levels}

How to stand for those who suffer violence in the local communities of miners located in conflict zones or high-risk areas? According to the conventional social justice framework implicit in the encyclical Populorum Progressio, one could identify two main priorities: on the one hand, creating the preconditions for integral human development, such us access to health, education and other material dimensions of well-being, as well as taking care of its symbolic and relational dimensions - the affective and spiritual bonds of those communities affected by violence. On the other hand, promoting integral human development should be related to the fight for social justice. If the former recalls the idea of solidarity between peoples, the latter reminds us that this solidarity should go beyond a paternalistic approach. It should aim to transform through collective actions those economic and social structures that are producing and reproducing the "situations of injustice". In the case of DRC and conflict minerals, this kind of approach should combine humanitarian action plans to fulfil the basic human needs -regardless of whether they are material or not- with other kinds of advocacy strategies in order to raise awareness of the situation on 
the ground and, ultimately, to introduce new trade regulations that break the links between trade and organized crime.

These kind of actions and strategies might help to mitigate the problem of "underdevelopment" as it was posed in the academic debates of the $60 \mathrm{~s}$ and the 70s. In fact, the mixture between humanitarian action, social and political advocacy has been present in the repertory of practices of many Faith Based Organizations since then. However, in the twenty-first century the "signs of time" have changed. It is not about "underdevelopment in poor countries" anymore, but about the global dynamics of capitalism and their unintended consequences such as increasing economic inequality, climate change, environmental degradation and so on. As Pope Francis argues in Laudato $\mathrm{Si}^{\prime}$, these manifestations of the social and ecological crisis of our time are not something we can ignore, because their roots are cultural and point out the unsustainability of our lifestyles.

If we read the issue of "conflict minerals" in the DRC though the lenses of Laudato $\mathrm{Si}^{\prime}$, the search for social justice should address not only the human right violations, the lack of transparency of global supply chains and the environmental impacts of mining, but the drivers behind the demand of $3 \mathrm{~T}$ and Gold, among other minerals. In other words, it must say something about the "throwaway culture" promoted by the electronic industries and our individual and collective responsibilities as consumers of electronic devices in a global world.

In this sense, ALBOAN's Campaign stands up for an all-encompassing "conversion" that goes from the social to the institutional, from individual action to collective action. Its message does not pretend to encourage technophobia. On the contrary, it aims to start a public conversation about the social and environmental impact of our consumption patterns of electronic goods. Global supply chains of minerals are complex systems that bring together many different actors and corporations across the world. They connect our reality as consumers with other people's reality as producers. Even if we do not experience how it does feel to be on the other side of the value chain we cannot skip our responsibility towards the rights of the people who occupy that place. "There are no innocent bystanders" says a famous saying, and by the same token it could be said that "there are no innocent consumers". As Pope Benedict XVI stated in his encyclical Caritas in Veritate (CV, 66), "purchasing is always a moral -and not simply economic-act-. Hence the consumer has a specific social responsibility, which goes hand-in-hand with the social responsibility of the enterprise". Therefore, according with the Social Teaching of the Church, in an increasingly globalised world we all have the moral duty as consumers to search as much information as possible about the ethical and environmental aspects of each product we purchase. 
ALBOAN and many other Civil Society Organizations (CSOs) involved in the Fair-trade Movement have a long way both to educate consumers and to increase transparency and control in the supply chains of the electronic industries. But despite the difficulties involved in this process, there are many things that can be done now. In this sense, during the last four years, ALBOAN's Campaign has developed different lines of work to promote change at the institutional, social and individual level. Inspired by the idea of conversion implicit in the Social Teaching of the Catholic Church, Table 1 summarizes ALBOAN's call for action with its Conflict-Free Technology Campaign.

\section{TABLE I. Conflict-Free Technology Campaign: three dimensions of change}

\begin{tabular}{|c|c|c|c|}
\hline \multirow{2}{*}{$\begin{array}{l}\text { General } \\
\text { aim } \\
\text { Types of } \\
\text { Conversion }\end{array}$} & \multicolumn{3}{|c|}{$\begin{array}{l}\text { Breaking the links between extraction and illicit trade on conflict minerals, } \\
\text { human right abuses in conflict zones and consumerism of electronic goods }\end{array}$} \\
\hline & Specific aims & Social practices & Target group \\
\hline Institutional & $\begin{array}{l}\text { - Follow up the Business } \\
\text { and Human Rights agen- } \\
\text { da (global) } \\
\text { - Pass EU/national laws } \\
\text { to regulate the trade on } \\
\text { conflict minerals (region- } \\
\text { al -national) } \\
\text { - Introduce ethical clauses } \\
\text { in the public procurement } \\
\text { ofelectronic goods (local) }\end{array}$ & $\begin{array}{l}\text { - Networking with CSOs } \\
\text { - Producing knowledge } \\
\text { - Monitoring theEurope- } \\
\text { an legislative process } \\
\text { and its implementation } \\
\text { - Establishing alliances } \\
\text { with private and public } \\
\text { sector }\end{array}$ & $\begin{array}{l}\text { - Policy and deci- } \\
\text { sion makers } \\
\text { - Activists } \\
\text { - NGO Networks } \\
\text { \& other CSOs }\end{array}$ \\
\hline Social & $\begin{array}{l}\text { - Promote an active global } \\
\text { citizenship } \\
\text { - Create a demand of } \\
\text { Conflict-Free Technology } \\
\text { - Reduce the social and } \\
\text { environmental impact of } \\
\text { electronic devices } \\
\text { - Fundraising money for } \\
\text { the projects in eastern } \\
\text { DRC }\end{array}$ & $\begin{array}{l}\text { - Spreading knowledge } \\
\text { and raising awareness } \\
\text { - Introducing "conflict } \\
\text { minerals" on the public } \\
\text { agenda } \\
\text { - Reusing and recycling } \\
\text { mobile phones } \\
\text { - Making teaching units, } \\
\text { educational materials } \\
\text { and guidelines }\end{array}$ & $\begin{array}{l}\text { - General public } \\
\text { - Influencers and } \\
\text { opinion leaders } \\
\text { - ALBOAN's Youth } \\
\text { Network } \\
\text { - ALBOAN's } \\
\text { Teachers } \\
\text { Network }\end{array}$ \\
\hline
\end{tabular}




\begin{tabular}{|l|l|l|l|}
\hline Personal & - Create capabilities to & - Signing ALBOAN's & - General public \\
become active citizens & petition in Change.org & - ALBOAN's stake- \\
- Improve social knowl- & - Reusing and recycling & holders (such as \\
edge about conflict & mobile phones & partners, volun- \\
minerals & - Volunteering in the & teers and so on) \\
- Reflect on the use and & Campaign & \\
consume of electronic & - Spreading the word & \\
devices
\end{tabular}

Source: By the author, based on the Conflict-Free Technology Campaign materials available at www. tecnologialibredeconflicto.org

Firstly, at the institutional level, the political advocacy strategy has been focused so far on the European legislative process. The aim was to gain influence over political leaders and decision makers at the national and regional level in the EU to pass a law strong enough to break the links between the illicit trade on the so-called "conflict minerals" and the human right abuses in high-risk conflict areas. The way to achieve this is promoting "due diligence" systems in line with the OECD's Guidelines in order to increase corporate accountability in the supply chain of minerals. This regulation was finally approved by the European Parliament and the Council last 19 May $2017^{8}$. However, the text agreed was not as strong as expected by the coalition of NGOs which followed up the negotiation process. The EU law will cover only direct importers of 3TG, which are around 300-400 companies, mostly smelters and refiners from different Member States; but leaves the "downstream companies" -the ones that import manufactured electronic goods- free to decide whether (or not) to follow the OECD's Guidelines.

The European NGOs were not satisfied by this decision", and many of them have decided since then to reinforce their work on the consumer side to create a demand of "responsible technology" 10 among the citizenship. In the Conflict-Free Technology

${ }^{8}$ The full text of the Regulation (EU) $2017 / 821$ is available at this website [last access 04.07.2017]: http://eur-lex.europa.eu/legal-content/EN/TXT/PDF/?uri=CELEX:32017R0821 \&from=EN

9 See EurAc's Network press release launched on November 22 ${ }^{\text {nd }} 2016$, after the agreement was reached: http://www.eurac-network.org/en/press-releases/eu-conflict-minerals-agreement-reached-exemptions-added

10 Even if the Campaign is called "Conflict-Free Technology" ALBOAN's advocacy officers prefer to use the expression "responsible technology", because the former can be misleading as there is no single electronic device "100\% clean". Using the latter expression, what they want to emphasize is the 
Campaign this will was present since the beginning, as ALBOAN's long experience promoting popular education and fair-trade products offered a unique opportunity to introduce the topic of responsible consumption of electronic goods to different publics. So, alongside the top-down approach implicit in the advocacy work towards the European legislative process, the Campaign also included two complementary bottom-up strategies aimed at raising awareness among the citizenship.

At the social level, most of the materials elaborated so far by the campaign team to keep the public on the loop of the international debates about conflict minerals have been specifically designed for schools and informal education programmes. Working this issue with young people has a multiplier effect that allows ALBOAN to reach a wider public and promote social change in the long-run. Most of the staff working in ALBOAN's Participation and Public Action Department has teaching experience and the necessary skills and methodologies to explain complex problems -such as the environmental conflicts triggered by mining- in accessible ways for the different kinds of public.

At the individual level, the bottom-up approach intends to create capabilities among ALBOAN's different stakeholders to become active citizens. The starting point for achieving this, according with the campaign team, is to raise awareness about our individual and collective responsibilities towards the social and environmental impacts caused by the current patterns of consumption and production of electronic goods. In order to create alternatives to consumerism, ALBOAN collects and recycles mobile phones ${ }^{11}$ and is also working on a proposal to promote Public Procurement of Electronic Goods. Regional and local Public Administrations are major consumers of electronic goods (such as, mobile phones, PCs and laptops). They invest millions of Euros every year in renewing their computer equipment and other devices. Hence, this new line of work aims to convince them to include ethical and environmental clauses in their contract documents with their authorized dealers to promote responsible sourcing of minerals among the companies that supply them with electronic goods. It also seeks to empower people making available to anyone the tools needed to do political advocacy in their communities, schools and organizations (e.g., collecting signatures, implementing specific guidelines, accompanying volunteers, etc.).

responsibility of governments and companies to conduct better due diligence processes on the whole supply chain following the OECD's Guidelines.

${ }^{11}$ For more information about the "Mobiles for Congo" initiative, visit the Campaign's website at: https:// www.tecnologialibredeconflicto.org/en/mobiles-for-the-congo/ 


\section{Concluding remarks}

One of the key ideas defended in this article is that the Social Teaching of the Church can be understood as an interpretation of social reality through the prism of Catholic religion. As such, it evolves alongside to the historical experiences that transform the world where Christians live. The message from God and truth revealed by Jesus Christ are still there, in the Holy Scriptures, but this kind of hermeneutical exercise made by the Social Teaching of the Church aims to provide Christians believers with an interpretation of how to embody that truth in a concrete historical context.

Originally, it was born to address the "social question" posed by the industrialization of Europe more than one century ago. However, since then, the idea of social justice and its practical implications in the defence of human dignity have had significant developments in the Social Teaching of the Church. The most relevant can be exemplified comparing the core ideas of two remarkable encyclicals: Populorum Progressio, published by Pope Paul VI in 1967 and Laudato Si' launched by Pope Francis in 2015. If the former gave the "social question" an international scope, interpreting the practice of development in Christian terms as Integral Human Development; the latter address the "social question" in the context of the current ecological crisis, introducing the idea of sustainability in the concept of Integral Human Development. In this sense, conceiving social justice as environmental justice has major implications not only from an ethical and theological standpoint, but in practical terms. It is a call to understand solidarity among peoples as something else than a social bonding between human beings, it is also a moral duty to take care of our "Common House" because it is the main legacy we can leave to the future generations.

The Conflict-Free Technology Campaign integrates the teachings of both encyclicals in its lines of work. On the one hand, it contemplates the question of Integral Human Development in the context of artisanal and small-scale mining communities and raises funds for the local organizations -such as the Jesuit Refugee Service- which "serve, accompany and advocate" on behalf of refugees and other forcibly displaced persons in the Great Lakes region. On the other hand, it addresses the underlying causes of environmental conflicts in the context of the ecological crisis whose roots, as Pope Francis points out, are cultural. That is the reason why the Campaign aims to promote a change of mentality -or "conversion"- at the institutional, social and individual level.

Over the years, the way to embrace change in these three levels has been evolving -and it will evolve- to adapt the Campaign's narrative to emerging realities. When 
Laudato Si' came out, soon after everything started, ALBOAN as a Jesuit NGO started a process of collective reflection which is the first stage in the journey towards its own "ecological conversion". It is a long and very challenging journey indeed and it affects many other aspects of the organization apart from the Conflict-Free Technology Campaign. But there are good reasons in Laudato Si' to carry on down the path undertaken by Pope Francis, and as he says at the end of his encyclical: "Let us sing as we go. May our struggles and our concern for this planet never take away the joy of our hope" (LS, 244).

\section{Bibliography}

BAUmAn, Z. (1991) Modernity and Ambivalence, Ithaca, N.Y., Cornell University Press.

- (2005) Work, Consumerism and the New Poor, Buckingham, Open University Press.

Deneulin, S. \& Bano, M. (2009) Religion in Development: Rewriting the Secular script, London, Zed Books.

International Labour Office (1976) Employment, Growth and basic needs: A oneworld problem, Ginebra, OIT/ILO.

Nussbaum, M. C. y Sen, A. K. (eds.) (1993) The Quality of Life, New York, Oxford University Press.

OECD (20132) OECD Due Diligence Guidelines for Responsible Supply Chains of Minerals from Conflict-Affected and High-Risk Areas, OECD Publishing. http:// dx.doi.org/10.1787/9789264185050-en

SACHS, W. (ed.) (1992) The Development Dictionary: A Guide to Knowledge as Power, London, Zed.

SEN, A. K. (1989a) "Development as Capability Expansion", Journal of Development Planning 19, 41-58.

Streeten, P., Javed Burki, S., ul HaQ, M., Hicks, N. \& Stewart, F. (1981) First Things First. Meeting Basic Needs in Developing Countries, London, Oxford University Press.

WAGNER, P. (2008) Modernity as Experience and Interpretation. A New Sociology of Modernity, Cambridge, Polity Press. 